\title{
Discussions on Identity in Ceramics and Ceramics in Contemporary Art
}

\author{
Esma Burcu Havasi \\ Osmaniye Korkut Ata University, \\ Faculty of Architecture, Design and Fine Arts, Ceramics Department, \\ Karacaoglan 80000 Campus Center, Osmaniye / Turkey \\ E-mail: esmasereli@gmail.com
}

\begin{abstract}
Clay, as a material and ceramics, which is the technique of hardening it by firing, is a form of production as old as human history like other branches of art. However, ceramics started to be perceived as contemporary art in the 20th century, when famous artists such as Pablo Picasso and Joan Miro made ceramics. Before this period, ceramics was being mentioned as; pottery, handicrafts and industry.

This process, which started with the production of ceramics by 20th century painters, allowed ceramics to be perceived as a contemporary art branch. In the years following this period in Europe, ceramics departments were opened within the academies, and with the contributions of those artists, who were educated in ceramics, as form and content, the style which is named as contemporary ceramic art today, has emerged. Thus, contemporary ceramic art, which was already born into modernism, has witnessed two periods until today; modernism and postmodernism.

The subject of this research is the study of the state reached by ceramics, which has had a unique modernization process and has been exposed to many discussions about its identity, in contemporary arts.
\end{abstract}

Keywords: Ceramic, Art, Craft, Identity, Art of Ceramics, Contemporary Art

DOI: $10.7176 /$ JSTR/6-10-10

\section{Seramikte Kimlik Üzerine Tartışmalar ve Güncel Sanatta Seramik}

Özet

Malzeme olarak kil ve onu ısıyla dayanıklı hale getirme tekniği olan seramik, diğer sanat dalları gibi, insanlık tarihi kadar eski bir üretim biçimidir. Ancak seramiğin çağdaş bir sanat olarak algılanmaya başlaması 20.yy‘da, Pablo Picasso, Joan Miro gibi ünlü sanatçıların seramik yapmalarıyla mümkün olmuştur. $\mathrm{Bu}$ süreçten önce seramikten; çömlekçilik, el sanatları ve endüstri olmak üzere üç şekilde bahsedilmektedir.

20.yy ressamlarının seramik üretmeleriyle başlayan bu süreç seramiğin çağdaş bir sanat dalı olarak algılanmasına olanak vermiştir. Avrupa'da bu dönemi izleyen yıllarda akademilerin içinde seramik bölümleri açılmış, buralarda seramik eğitimi alan sanatçıların biçim ve öz olarak seramiğe kazandırdıkları yeni formlarla; bugün çağdaş seramik sanatı diye adlandırılan biçem ortaya çıkmıştır. Böylelikle hali hazırda modernizmin içine doğmuş olan çağdaş seramik sanatı, günümüze kadar modernizm ve postmodernizm olmak üzere iki döneme tanıklık etmiştir.

Kendine özgü bir çağdaşlaşma süreci geçiren ve bu süreçte kimliğiyle ilgili pek çok tartışmaya maruz bırakılan seramiğin güncel sanatta ulaştığı durumun incelenmesi, bu araştırmanın konusunu oluşturmaktadır.

Anahtar Kelimeler: Seramik, Sanat, Zanaat, Kimlik, Seramik Sanatı, Güncel Sanat

114 | P a g e

www.iiste.org 


\section{Giriş}

Seramik insanoğlunun eşya yapmak için kullandığı ilk malzemelerden biridir. Şekil almaya elverişli yapısıyla kil, pişirildikten sonra sertleşip dayanıklı hale gelmesi, perdahlama ve sırlama teknikleri sayesinde geçirgenliğinin de azalmasıyla, insanoğlunun Neolitik Çağ'dan beri hayatında önemli bir yer tutmaktadır. "Çanak-çömlek yapımının ilk kez nerede gerçekleştirildiğine dair kesin verilere ulaşamamakla birlikte Anadolu ve Yukarı Mezopotamya'da birçok yerleşmede gerçekleştirilen arkeolojik kazılarda, İ.Ö. 6000'lere tarihlenen örneklere rastlanmıştır” (Erman, 2012: 20). Yani özetle söylenebilir ki; çömlekçilik, insanların tarıma geçmesiyle duydukları kap-kacak ihtiyacı neticesiyle ortaya çıkmıştır ve seramiğin endüstrileşmesi konusunda atılan ilk adımdır.

Çömlekçiliğin zaman içerisinde gelişmesi, teknoloji ve pişirim tekniklerinin ilerlemesi ve insanoğlunun estetik kaygılarının artması ise, el sanatları sürecini başlatmış ve el sanatlarının da gelişip, sanayi devrimi ile birlikte seri üretime geçilmesiyle, bugün anladığımız anlamıyla seramik endüstrisi doğmuştur.

Seramiğin sağlığa uygun bir malzeme olması; çömlek yapımı, el sanatları ve endüstride yoğun şekilde kullanılmasını beraberinde getirmiş, uzun yıllardır yapılan ve nihayet günümüzde sönümlenmiş gibi görünen fakat zaman zaman yeniden alevlenen "seramik sanat mıdır, zanaat mıdır?" tartışmalarının da bir bakıma nedeni olmuştur.

Bugün, güncel sanat içinde, seramik üreten sanatçıların üzerine yoğunlaştığı konular; genellikle seramiğin sanat üretme yolunda geçirdiği kimlik bunalımıyla doğrudan ilişkilidir. Sanat dallarının belirgin sinırlarının ortadan kalktığı ve hemen her malzemenin ve konunun sanat tarafindan kucaklandığı günümüzde, seramik malzeme ile üretim yapan sanatçılar da artık daha önceleri kendileri için eleştiri konusu yapılan özelliklerin bizzat üzerine giderek bu durumu çağdaş sanata yaraşır şekilde, ironik bir anlatımla, avantaja çevirmeyi başarmışlardır.

\section{1. Çömlek, El Sanatları ve Endüstriyel Olarak Seramik}

Şekillendirme ve pişirme tekniği açısından günümüzde anlaşıldığı şekilde yapılan ilk seramik çömlek örnekleri Neolitik dönemi işaret etmektedir. İnsanların tarıma geçtiği dönem olarak bilinen "Neolitik Çağın sonlarında elde yapılan iyi perdahlanmış ve basit geometrik desenlerle bezeli seramik kaplara rastlanmaktadır" (Anadolu Medeniyetleri Müzesi, 1997: 25) (Görsel 1). İlk seramik örnekleri anlaşıldığı gibi sanatsal kaygılardan çok ihtiyaçtan ortaya çıkmıştır. Yerleşik düzene geçen ve tarım ile uğraşan toplumlar doğal olarak dayanıklı kap-kacaklara ihtiyaç duymuşlardır.

“M.Ö. 3000'lerde çömlekçi çarkının bulunmasıyla", seramik konusunda üretim biçimi adeta ivme atlamış, daha dayanıklı, daha hızlı ve daha estetik seramik objeler üretilmeye başlanmıştır (Anadolu Medeniyetleri Müzesi, 1997: 62). Çömlekçiliğin doğuşu ile birlikte başlayan bu seri üretme tarzı beraberinde insanlara ürünlerin üzerini süsleyecek zamanı da kazandırmış ve çeşitli dekorlama biçimleri geliştirilmiştir. Bu dekor teknik ve desenlerinin, her kültürde, o kültürün özelliklerine göre gelişmesi ile seramikten artık bir el sanatı olarak bahsetmek mümkündür.

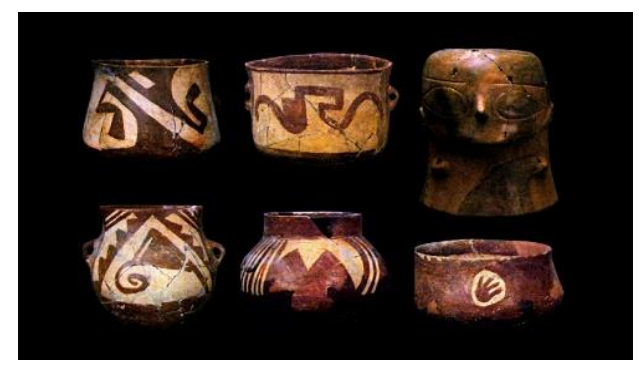

Görsel 1. Burdur Hacılar Seramikleri, İ.Ö.6.bin yı1 2.yarısı

Doğu kültüründen ortaya çıkıp Anadolu'da özgün örnekler geliştiren çini sanatı; "sanat tarihinde İslam mimarisini ve ona paralel gelişen seramik sanatını çağrıştırmaktadır. Türk, İran, Moğol, Arap ve Berber asıllı toplumların Orta Asya'dan İspanya'ya kadar uzanan geniş coğrafyada 7. yüzyıldan çağımıza kadar geliştirdikleri çini ve seramik sanatı, dönem ve ülkelere göre farklılıklar ortaya koyar. Bu gelişme çizgisinde Selçuklu'dan Osmanlı Devri sonuna kadar çini ve seramik sanatı oldukça özgün ve ilklere damgasını vuran özellikler sunar. İslam sanatında farklı bölge ve devirlerde görülen yeniliklere rağmen, müşterek detaylar, süsleme ve mimari özellikler dikkati çeker” (Öney ve Çobanl1,2007:13) (Görsel 2).

115 | P a g e

www.iiste.org 


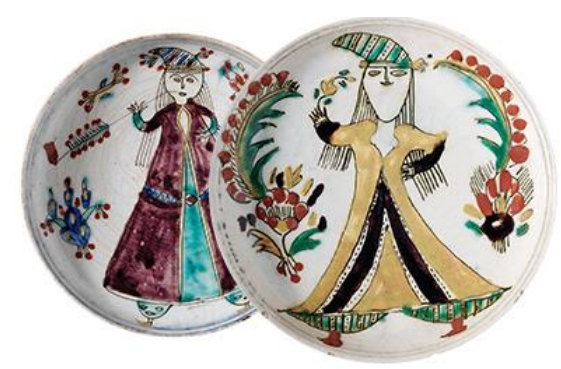

Görsel 2. Kütahya Çini Örneği, Pera Müzesi Kütahya Çini ve Seramikleri Koleksiyonu

Yine sır altı ve sır üstü gibi çeşitli dekor teknikleriyle yapılan Yunan Vazoları, siyah figürlü dönem ve kırmızı figürlü dönem olmak üzere iki grupta incelenir ve tarihi ya da mitolojik öykülerden sahneler ile bezenmektedir (Görsel 3).

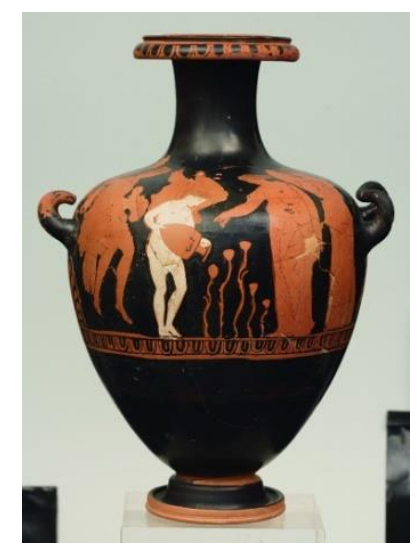

Görsel 3. Kırmızı Figürlü Yunan Vazosu, Çiçek Sulayan Eros, M.Ö.374-350

İtalyanlara özgü bir dekor biçimi olan "Majolica" ise İspanya'dan 13.yy'da İtalya'ya gelmiştir. “Araplar bu tekniği, Endülüs Emevi Devleti zamanında İspanya'ya götürmüşlerdir. Buradan da Mollorca adası vasıtasıyla İtalya'ya geçen Majolica, buradan Avrupa'ya yayılmıştır” (Turani, 2004: 88). Bu teknikte, form önce beyaz sırla kaplanır, üzerine boya ve oksitlerle dekor uygulanarak pişirilir. Genellikle figür ve bezemenin birlikte kullanıldığı Majolica stilinde, desenlerin arasında bir yerde mutlaka, ya seramiği yapan ya da sipariş eden kişiye yönelik bir yazı bulunur (Görsel 4). Uzakdoğu ise, seramik ve el sanatları bakımından oldukça iyi örneklerin sergilendiği bir coğrafya olarak karşımıza çıkmaktadır. "Çini”" ve pek çok sır altı tekniği dünyaya bu coğrafyadan yayılmıştır. Japon ve Çin seramiklerinde süsleme ve bezeme açısından son derece özgün örneklere rastlanmaktadır.

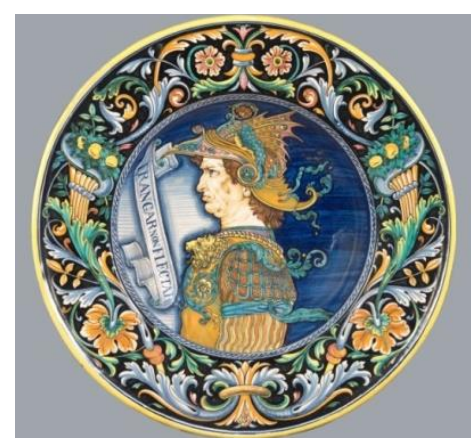

Görsel 4. David Zipirovic, Majolica, Deruta, 1923-1927

18.yy'da İngiltere'de başlayan “Endüstri Devrimi’ne” kadar seramik el sanatları olarak kendisini teknik 
ve malzeme dahilinde oldukça geliştirmiş, dünyanın hemen her yanında kültürler, yukarıda sayılan eşsiz tarz ve biçimleri oluşturmayı başarmışlardır. Bu büyük gelişme seramiğe her ne kadar teknik ve üretim koşullarında büyük kolaylıklar getirmişse de, "Endüstri Devrimi ile İngiltere'deki geleneksel üretim yapan çömlekçi atölyeleri, hızlı ve ucuz üretim mantığıyla, tek düze, yoz, süslü ve ucuz seramik ürünler sunmaya başlar” (Uludağ, 1998: 36) (Görsel 5).

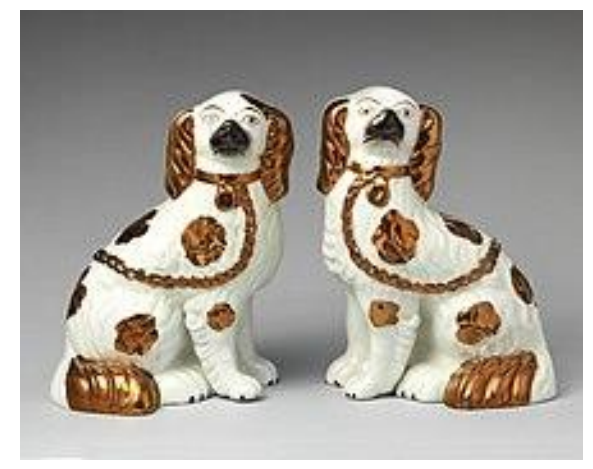

Görsel 5. 1830-50’lere ait bir çift Spaniel cinsi köpek biblosu

“Böylelikle 19.yy sonlarında “Endüstri Devrimi’ni insanlığın kendisine getirdiği en büyük felaket olarak gören William Morris, “El Sanatları ve Sanat” (Arts and Craft) akımını başlatmıştır” (Tansuğ aktaran: Uludağ, 1998: 36). Morris, Victorya Dönemi'nin ucuz ve kötü seri üretim mallarının niteliksizliğini vurgulayarak, geçmişin el sanatlarına dönmeyi amaçlamıştır. Ancak el yapımı ürünlerin tek ve çok pahalı olması sebebiyle geniş kitlelere ulaşamaması yine ucuz seri üretim malların tercih edilmesine sebep olmuştur. Böylece Morris, sonraki nesillerce sanat ve el sanatlarını değil ama sanat ve endüstriyi birleştirmeyi başarmıştır.

$\mathrm{Bu}$ dönemden itibaren seramiğin bir endüstri olarak çok geliştiğini, banyo-mutfak endüstrisinin ve tasarımlarının da ilerlemesiyle mimaride bir malzeme olarak başköşede yer aldığını gözlemlemek mümkündür. Öyle ki Bauhaus, Art Deco gibi mimari akımlar kendi seramik tarzlarını oluşturmuşlardır. Günümüzde seramik tasarımı sanatsal fikirler taşımakta, artık pek çok fabrika tasarımcılarla çalışmakta ve markalara özel tasarımlar yapılmaktadır.

\footnotetext{
"Bugün artık bir bilim dalı da olan seramik, günümüz teknolojisinde inanılmaz olanaklar sunmaktadır. Bunun en iyi göstergesi, uzay araçlarının dışının yüksek ısıya dayanıklı seramik yüzeyle kaplanmasıdır. Günümüzde bükülebilen, görevi bitince de yok olabilen seramikler yapılmaktadır Birçok endüstri alanına yayılarak üretilen seramik, günümüzde yapı ev eşyası seramikleri dışında elektrik refrakter, aşındırıcı, nükleer, mekanik ve süper iletken seramikler olarak endüstri yaşamında yer almaktadır” (Çolakoğlu aktaran: Salman Çevik, 2009: 561).
}

\section{20.yy'da Seramik Yapan Sanatçılar ve Seramiğin Sanat Olarak Tanınması}

20.yy.'a kadar yukarıda anlatılan gelişmeleri ve değişimi yaşayan seramik, bu tarihten önce resim ve heykel gibi bir "klasik" ya da "yüksek" sanat alanı olarak görülmemiştir. Geçirdiği farklı süreç göz önüne alındığında bu doğal bir sonuçtur. Resim ve heykel mimarinin içinden kopup gelmiş ve kendi bağımsız varlıklarını ortaya koymuştur, oysa seramik bir el sanatı olarak gelişim göstermiş ve tam tersine mimari ile 20.yy'da buluşmuştur.

"Modern dönemin öncü sanatçıları, Pablo Picasso, Joan Miro, Marc Chagal, Georges Braque, Paul Gauguin, Fernard Leger, Jean Cocteau ve Cobra Grubu seramiği bir malzeme olarak değil, sanatsal bir ifade aracı olarak görmüşlerdir. Bu gelişim seramiğin sanatsal dönüşümüne önemli bir katkı sağlamıştır” (Boz, 2011: iii.) (Görsel 6, 7, 8, 9). Paul Gaugain 'in 1800'lerde seramiğe ilgi duymasıyla başlayan seramik yapma serüveni 20.yy sanatçıları için deneysel bir alan olmuştur. Bu dönem sanatçıların seramik ile ilgili bir biçim arayışları yoktur. Seramik ile kurulan ilişki daha çok ressamların kendi sanat dillerini seramik üzerine resimsel olarak aktarmaları şeklindedir. 


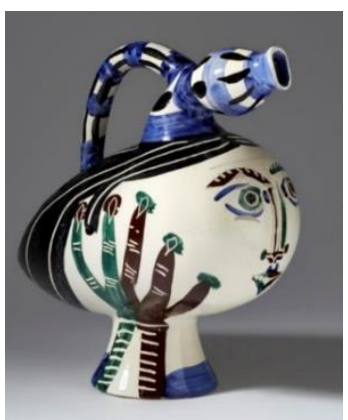

Görsel 6. Pablo Picasso, Duck flower-holder, 1951, Ceramic, 42.5 x 21.5 x $45 \mathrm{~cm}$.

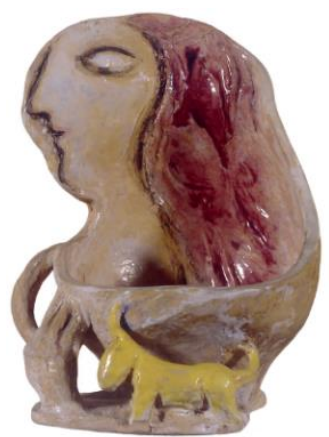

Görsel 7. Marc Chagall, Sculpted Vase, 1952, Ceramic, y:114,3 cm.

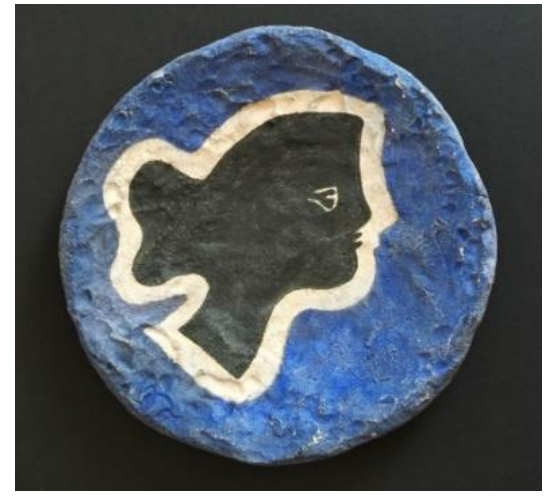

Görsel 8. Georges Braque, Plate, 1960, Ceramic, 27.3 x 27 cm.

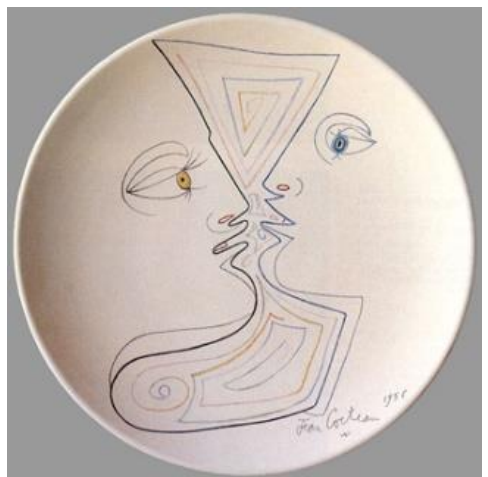

Görsel 9. Jean Cocteau, The Desire, 1958, Porcelain, R:30 cm 
Bu konudaki istisnai isim Joan Miro'dur. Miro $40 l_{1}$ y1llarda yaptığı seramiklerde söz konusu diğer sanatçılar gibi resimsel aktarımlarda bulunmuş ancak 80li yıllara kadar seramik yapmayı sürdürmüş ve 50li yıllardan itibaren iyice belirginleşen bir seramik form arayışına girmiştir (Görsel 10).

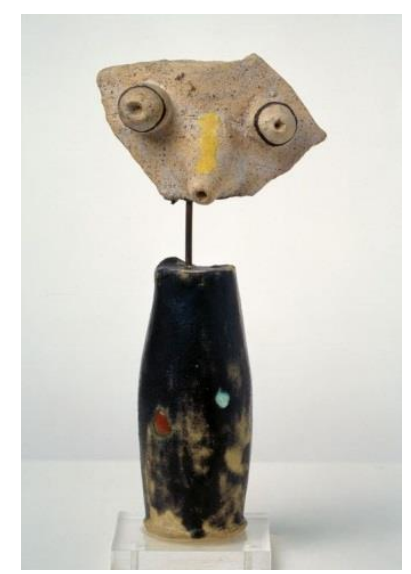

Görsel 10. Joan Miro, Figürine, ,1956, Ceramic Form, 21x10,5 cm.

1950'lerde Cobra Grubu'nun yaptığı seramikler ise daha özgün nitelik taşırlar. Ali Artun'a göre “Cobra, 2. Dünya Savaşı'ndan hemen sonrasında Dada ve Sürrealizmin mirasına sahip çıkan ilk avangart canlandırmalardan biridir. Cobra Sanatçılarına göre, bütün estetik kurallar reddedilmelidir. Böylece ifade dürtüsü özgürleşecek, herkes her türden sanatı üretebilecek, sanat günlük ve gündelik hayatla kaynaştırılacaktır."1 Grup sanatçılarının o döneme kadar görülmemiş şekilde seramik malzemeyi işlerinde sıklıkla kullanmalarında; sanatı günlük ve gündelik kullanıma yaklaştırma çabalarının etkisi olduğunu düşünmek mümkündür (Görsel 11).

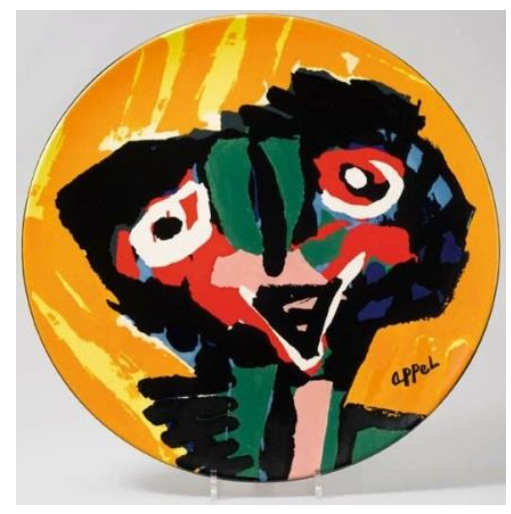

Görsel 11. Karel Appel (Cobra), Ceramic Plate, 1972, Creamic, R:50 cm.

20.yy yıl ressamlarının bu deneysel alana giriş yapmaları, Avrupa'da insanların seramiğe olan bakış açısını değiştirmiş, yüzyılın başından itibaren çeşitli Avrupa kentlerinde akademilerin içinde hızla seramik bölümleri ve başta İngiltere'de Bernard Leach ve ABD'de Peter Voulkos olmak üzere çeşitli sanatçılar tarafından özel seramik atölyeleri açılmaya başlanmıştır. Buralardan yetişen seramik sanatçıları artık seramiğe özgün bir form vermeyi ve plastik sanatlar ile ortak bir dil yakalamayı başarmışlardır.

\section{1950-1970 Modernizm Etkisinde Seramik (Seramikte Yeni Biçim Arayışları)}

"Modernizm, eskiden yeniye geçiş, zamanın yeniliklerine uyma" anlamlarına gelen çok geniş bir kavramdır (Şahindokuyucu. 1997: 9). Dolayısıyla her çağın içinde modern bir dönemden bahsedilebilir.

${ }^{1}$ A. (Temmuz, 2012). CoBrA, eSkopbülten Sanat Tarihi Eleştiri. Web: https://www.e-skop.com/skopbulten/cobra/806 119 | P a g e

www.iiste.org 
Tez çalışmasında Melek Şahindokuyucu bu konuyu şöyle açıklamaktadır:

"Genel olarak her çağın getirmiş olduğu yeni düşünce, eylem hatta kanun, örgüt ve sanatı, daha evvelki çağların bu tür insancıl faaliyetleri karşısında modern bir karakter taşır. Modernizm sözlük anlamıyla yenilik ve çağcılık demektir. Felsefede yeni teoriler, pozitif bilimlerde yeni buluşlar, kendilerini hazırlamış olan eski çalışmalara oranla moderndirler ve bunlar, yeni hayatın, yeni zevk ve zekânın ihtiyaçlarını karşılarlar. Hiç şüphesiz bunlar da yerlerini ilerde, kendilerinden daha yeni, yani daha modern olan eser ve buluşlara terk edeceklerdir. Bu ilerlemenin en temel kanunudur" (Senağ aktaran: Şahindokuyucu, 1997: 2).

Alıntıda işaret edildiği gibi 20.yy, endüstri, teknoloji, felsefe, pozitif bilimler, sanat, kültür gibi pek çok alanda ilerleme ve değişimlerin yaşandığı bir çağ olması sebebiyle, "modernizmin" başlı başına bir kavram olarak tartışıldığı ve hissedildiği bir dönem olmuştur. Sanatta da kaçınılmaz olarak eski ve klasik sayılan anlayışın terk edildiği, yeni bir ifade biçimi ortaya çıkmıştır. Bu dönem, başta resim ve heykel olmak üzere sanat dallarını içine alan, pek çok çağdaş sanat akımının doğduğunu ve birbirlerini etkileyerek ya da karşıtlık içerisinde geliştiklerini gözlemlemekteyiz.

Seramik alanında 50’ler kuşağı olarak bahsedebileceğimiz kuşak, seramiğin kendi geleneğini göz ard1 etmeden ama daha çok gelenekten kopuşunu konu edinen, soyutlama yoluyla yeni bir dil oluşturmayı başarmıştır. Modern seramiğin artık, el sanatları dönemindeki süs ve bezemeden neredeyse tamamen uzaklaştığını, alışıla gelmiş taşınabilir seramik formlardan seramik tekniğini de zorlayan devasa formlara dönüştüğünü rahatlıkla gözlemleyebilmekteyiz. Bu yeni sanat alanı Avrupa'da heyecan uyandirmış,
"20.yy başlarında özellikle LEACH Ekolü ile başlayan ve misafir sanatçıların katılımlarıyla hızlı bir ivme kazanan Modern Seramik Sanatı Avrupa'nın birçok ülkesinde ses getirmiştir. Geleneksel kap sanatı, sanki kabuk değiştirmeye başlamış ve geleneksel muhafazakârlıklarını yavaş yavaş üzerinden atarak yeni düşünceler, heyecanlar ve genç seramikçilerin aktif çalışmaları ile yeniden doğmuştur. Bu sanat sanki öncesinde hiç yokmuş, binlerce yıldır insan ile iç içe yaşamamış gibi, yeni keşfedilen bir malzemeye duyulan merak ve heyecanla, seramik sanatı artık modern sanatçıların ellerinde yeniden yaratılmıştır" ( Şahbaz, 2006: 23).

Döneme damga vuran sanatçılar, kendi atölyelerini adeta okula dönüştüren Bernard Leach ve Peter Voulkos’tur. Bu dönemin "soyut seramik" diye adlandırılan türde üretim yapan diğer önemli sanatçıları; aynı zamanda heykeltıraş olan İsamu Noguchi, Georges Jouve, Guido Gambone, Jun Kaneko, Leza Mcvay, Toshiko Takaezu, Rudy Autio'dur (Görsel 12).

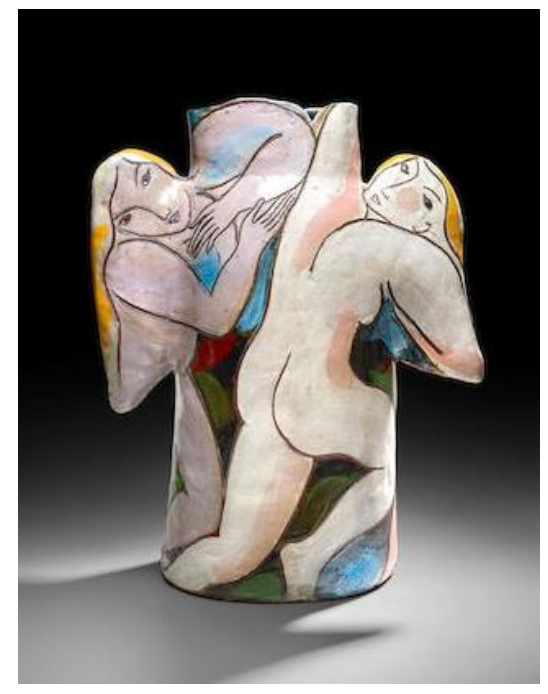

Görsel 12. Rudy Autio, Untitled, 1987, Glazed Ceramic, h:62,5 cm.

Seramik geleneği Anadolu toprakları için köklü, önemli ve özel bir yere sahiptir. Türkiye'de çömlekçilik ve el sanatları süreçleri Avrupa ile benzer şekilde gelişim göstermiş ve Cumhuriyet sonrası dönemde "çağdaş seramik" de, hemen hemen Avrupa ile eş zamanlı olarak ülkemizde etkili olmuştur. $\mathrm{Bu}$ etkide Cumhuriyet Dönemi'nde bir devlet politikası olarak çağdaşlaşma yolunda sanata önem verilmesinin payı büyüktür. Akademiler, akademilerde yeni bölümler ve sanat okulları ardı arkasına 120 | P a g e

www.iiste.org 
açılmış ve buralardan yetişen öğrenciler yurtdışında eğitim almak amacıyla devlet bursuyla Avrupa'ya gönderilmişlerdir. Bu sanatçılardan Hakkı İzzet ve İsmail Hakkı Oygar yurtdı̧̧ındaki eğitimlerinden döndükten sonra akademik olarak Türkiye'de seramik eğitiminin başlamasında öncülük etmiş, Füreya Koral, Alev Ebuziya gibi sanatçılar ise serbest çalışmalarıyla akademinin dışında seramik sanatının gelişiminde katkıda bulunmuşlardır.

1950-1970 arası dönemi kısaca, Türk seramik tarihi açısından da sanatta modernizmin doruk noktasının yaşandığı, "soyut seramik" kavramının akademilerden serbest sanatçılara kadar nerdeyse amaç edinildiği bir dönem olarak gözlemlemek mümkündür (Görsel 13).

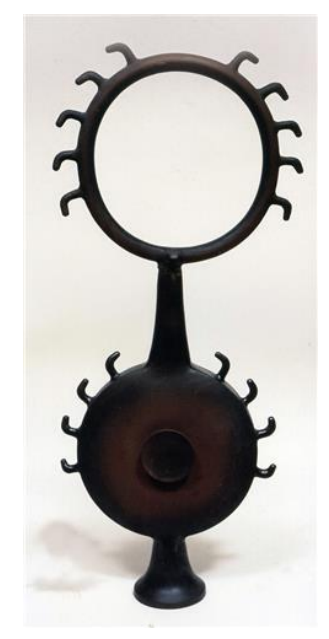

Görsel 13. Sadi Diren, İsimsiz, 1970, Seramik, 100 x 50 x $15 \mathrm{~cm}$.

\section{1970'den Günümüze Postmodernizm Etkisinde Seramik}

Postmodernizm kavramı, basit şekilde "modern sonrası" olarak ifade edilir. Endüstri devriminin ürettiği yeni yaşam biçimi nasıl moderniteyi yarattıysa, bu sürecin devamında ortaya çıan tüketim toplumu da postmodernizm kavramının doğmasına yol açmıştır. Ağırlıklı olarak 1960lardan sonra, mimari, edebiyat/şiir gibi alanlarda hissedilmeye başlanan bu değişim, 70ler ve sonrasında giderek sanatın her alanında hissedilir hale gelmiştir. Modern dönemin ürettiği akla dayalı, kuralcı, sade ve biricik sanat yapıtına karşılık postmodern süreç, sanatı bu kutsanmışlı̆̆ın dışına çıararak; zaman, mekân, konu ve malzeme gibi pek çok bileşeni sonsuz bir çeşitlilik içinde bir arada kullanmaya yönelik yeni bir üslup geliştirir. "Bu yüzden postmodernist uygulamalarda (video ve fotoğraf da dahil, modernizminkinden farklı yada modernizmin ihmal ettiği) çeşitli araç ve yöntemler özellikle kullanılmaktadır" (Şahin. 2012: 105).

Postmodernizm sürecinde seramik de artık başka malzemeler, başka ifade biçimleri ve teknoloji ile birleşerek melezleşme yaşamaktadır. Ayrıca günümüz sanatında seramik sanatçıları, konunun başından beri açıklanan, seramik malzemenin "çömlek, el sanatı, endüstri’" olma özellikleri yüzünden, şüphe ile yaklaşılan ve eleştirilen yönlerinin üzerine giderek seramiğe yeni ve cesur bir duruş kazandırmışlardır. 70lerden günümüze seramiğin üzerine eğildiği en önemli konular; "feminizm" (feminist sanat), "zanaat-sanat ilişkisi”, "fonksiyon sorunsalı" (klasikleşmiş fonksiyonel seramik formların fonksiyonunu yok etme), "mimari ve kent", "biçim, fonksiyon ve anlam olarak nesne", vb.dir. Postmodernizmin ironik dilinden payına düşeni alan seramik sanatçıları günümüzde bu dili eserlerinde siklıkla kullanmaktadırlar.

Judy Chicago'nun tarihçiler tarafından ihmal edilmiş olan kadın sanatçıların başarılarını kutlamak için tasarladığı "Akşam Yemeği Partisi”, 70'li yıllarda feminist düşüncenin ikonu haline gelmiştir (Görsel 14). Bu öncü hareketten sonra feminist sanatçılar, geleneği yeniden değerlendirmek ve hatta yıkmak için tarihi olarak kadını akla getiren zanaat tekniklerini benimsediler. Bu bağlamda feminist sanatçıların sıklıkla kullandıkları malzemelerden biri de seramik olmuştur (Görsel 15). 


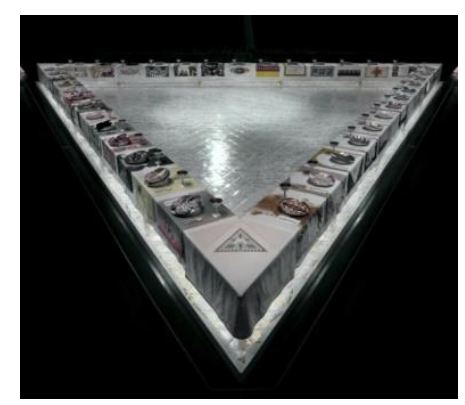

Görsel 14. Judy Chicago, Akşam Yemeği Partisi, 1974-79, Ceramic, porcelain, textile, $1463 \times 1463 \mathrm{~cm}$.

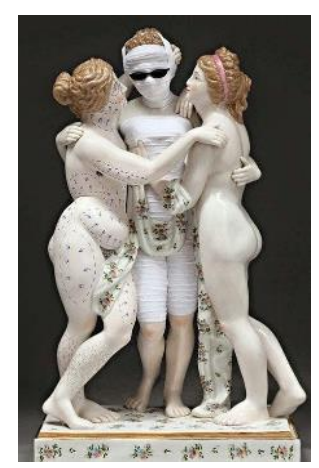

Görsel 15. Penny Byrne, Keep Young and Beautiful if You Want to be Loved, 2011, Vintage porcelain figurines, mixed media, $40 \times 26 \times 21 \mathrm{~cm}$.

Zanaat ve geleneği sorgulama ve ona yeni bir nitelik kazandırma yolunu seçen güncel sanatçılar, 19.yy. geleneksel biblo formları gibi kalıplaşmış formlara, güzel ve estetik kavramlarını alaşağı eden yeni anlamlar yüklemişlerdir. Artık izleyici, sevimli ve güzel olmasına alışkın olduğu herhangi geleneksel bir formun tiksindirici tarafiyla yüzleşir ve adeta şoka girer. Bu tavrın amacı; izleyiciyi bilinçli olarak sarsmak ve bu yeni biçim ve onun forma kazandırdığı yeni anlam üzerine düşünmesini sağlamaktır (Görsel 16).

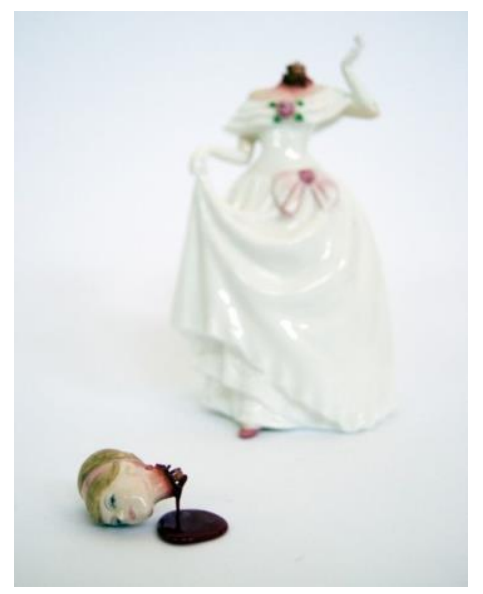

Görsel 16. Jessica Harrison, Ruby, 2010, Found ceramic, epoxy resin, enamel paint, 19 x 11 x $11 \mathrm{~cm}$

Kullanılabilir seramik eşyaların fonksiyonunu bozmak ise günümüzde, seramik üreten sanatçıların başka bir yönden kimlik tartışmalarının üzerine gitme yoludur. Finlandiyalı sanatçı, Caroline Slotte ve İngiliz sanatçı Livia Marin "kırık şeyler" serisi ile eşyanın fonksiyonu üzerine ilginç yaklaşımlar getirmişlerdir (Görsel 17).

122 | $\mathrm{P}$ a g e

www.iiste.org 


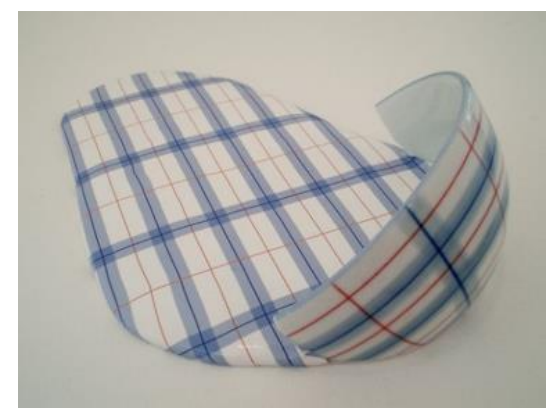

Görsel 17. Livia Marin, Broken Things, 2009, Ceramic

Kavramsal sanatın en önemli isimlerinden biri olan Ai Wei Wei, yaptığı porselen ay çekirdeği yığınıyla fikrin karşısında malzemenin yalnızca bir araç olduğunu en açık haliyle bir kez daha göstermiştir. Bilindiği üzere, Çinli sanatçı, kalabalık Çin nüfusunu ve Çin'deki ucuz iş gücünü 100 milyon ay çekirdeği ile ifade etmiştir (Görsel 18).

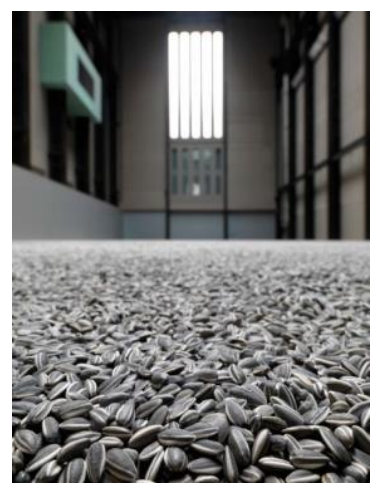

Görsel 18. Ai Wei Wei, Sunflower Seeds, 2010, Düzenleme /Hand-crafted in Porcelain

Performans, enstalasyon ve digital sanat gibi, güncel sanat içinde artık yaygın bir dile dönüşen diğer ifade biçimleri ile seramik, kil malzemenin her şekle girmesi, kolay biçim değiştirmesi gibi özellikleri nedeniyle kullanılabilmektedir. "Stopmotion" animasyon tekniğinin öncelikle "claymotion" denilen teknikten doğduğu bilinmektedir. 1953 yılında yaptığı ilk "claymotion" film ile hikâye kaygısı taşımayan ABD'li sanatçı Art Clokey, "Gumbasia” adlı kısa animasyon filmi ile kil malzemenin bütün özelliklerini gözler önüne sermiştir. Performans alanında ise Fransız sanatçı Olivier de Sagazan yüzüne sürdüğü üst üste çamur katmanlarını her defasında başka bir yüz oluşturmak için kullanmakta, böylece git gide kendi kimliğinden uzaklaşıp bir çeşit metamorfoz geçirmektedir.

Görülmektedir ki; güncel sanatta bütün malzemelerin olduğu gibi seramik de, akla gelen ve belki de henüz akla bile gelmeyen şekillerde, sanatçının oyun alanı içinde yerini almıştır.

\section{Sonuç}

Seramik, görünen o ki; sahip olduğu bütün fonksiyonel özellikleri ile resim ve heykelden farklı bir süreç yaşamıştır. 20.yy. başlarında ünlü ressamların seramik yapması ile çağdaş bir sanat olarak algılanması mümkün olmuş, modernizm ve postmodernizmin sanat üzerindeki etkilerini resim ve heykel gibi diğer sanat dallarıyla eş zamanlı olarak yaşamıştır. Günümüzde yaşanan "bilgisayar devrimi” ile teknoloji ve dijital dünyanın getirisi olan tüm değişimlerden diğer sanat dalları ile aynı etkiyi almış, fikir ve kavramın, malzemenin ve el üretiminin önüne geçtiği günümüz dünyasında, önceden dezavantaj gibi görülen; zanaat, fonksiyon gibi özelliklerinin üzerine giderek, yeni ve kavramsal bir dil oluşturmayı başarmıştır. İsminin bir malzemeyi tanımlıyor olması, malzemeye olan bağlılıktan kopmayı biraz geciktirip, sahip olduğu karmaşık teknikler yığını sebebiyle üretim süreci, çağın hızına yetişmeyi biraz güçleştirse de; performans, enstalasyon gibi farklı ifade biçimleri ve hatta üç boyutlu yazıcıların hayatımıza girmesiyle kaçınılmaz olarak değişim yaşadığı gözlenmektedir.

123 | P a g e

www.iiste.org 
Gelecekte seramik, ya el ve emek gücünü tamamen terk edecek ya da tamamen dijitale dönüşmüş bir ortamda bu özelliğinin avantajlarına sarılarak, geliştirdiği yeni söylemlerle var olmaya devam edecektir.

\section{Kaynakça:}

Anadolu Medeniyetleri Müzesi. (1997) Anadolu Medeniyetleri Müzesi. Ankara: Dönmez Offset Müze Eserleri Turistik Yayınları.

Artun, A. (Temmuz, 2012). CoBrA, eSkopbülten Sanat Tarihi Eleştiri. Web: https://www.eskop.com/skopbulten/cobra/806 adresinden 30 Ocak 2020'de alınmıştır.

Boz, G. (2011). İroni Kavramının Postmodern Dönüşümü ve Postmodern Seramik Eserlerde İroni, Yüksek Lisans Tezi, Eskişehir Anadolu Üniversitesi Güzel Sanatlar Enstitüsü, Eskişehir.

Erman, Onur, D.(2012). “Türk Seramik Sanatının Gelişsimi: Toprağın Ateşle Dansı”, Çevrimiçi Tematik Türkoloji Dergisi, 4(1), 18-33.

Salman Çevik, N. (2009). "Hacılar Antik Yerleşkesinde Bulunan Seramik Kaplar Üzerindeki Bezemelerin Plastik Açıdan Incelenerek Artistik Yüzey Değerlendirmesinde Bireysel Etkileri”, GÜ, Gazi Eğitim Fakültesi Dergisi, 29(2), 557-574.

Şahbaz, H.(2006). Modern Seramik Sanatında Minimalizm, Yüksek Lisans Tezi, Eskişehir Anadolu Üniversitesi Sosyal Bilimler Enstitüsü, Eskişehir.

Şahin, Hikmet. (2012). “Postmodern Sanat”, İdil Dergisi 5(1), 90-111.

Şahindokuyucu, M.(1997). Bir Kavram Olarak Modernizm ve Resim Sanatına Etkileri, Yüksek Lisans Tezi, Abant İzzet Baysal Üniversitesi Sosyal Bilimler Enstitüsü, Bolu.

Turani, A. (2004). Sanat Terimleri Sözlüğü. İstanbul: Remzi Kitabevi.

Uludağ, K. (1998). Seramik Sanatının Kimlik Sorunu, Türkiye'de Sanat Dergisi, 33, 36-38.

Öney, G. ve Çobanll, Z. (Editörler). (2007). Anadolu'da Türk Devri Çini ve Seramik Sanatt. İstanbul: T.C. Kültür ve Turizm Bakanlığı Yayınları.

\section{Görsel Kaynakları:}

Görsel1.http://www.gateofturkey.com/section/tr/423/7/kultur-ve-sanat-anadoludaki-uygarliklaranadoluda-ilk-yerlesimler-hacilar\#prettyPhoto (erişim:17.01.2020)

Görsel 2. https://www.peramuzesi.org.tr/Sergi/Kutahya-Cini-ve-Seramikleri/79 (erişim: 20.01.2020)

Görsel 3. https:// www. namuseum. gr/ en/ collection/ ysteri- klasiki- proimi- ellinistiki/ (erişim: 20. 01.2020)

Görsel4.https:// www. museoceramicadideruta.it/ en /museum- storage- collections_3/pag2 / ( erişim : 20. 01.2020)

Görsel 5. https://en.wikipedia.org/wiki/Staffordshire_dog_figurine (erişim 09.02.2020)

Görsel 6. https://www.hku.hk/press/news_detail_11613.html (erişim 09.02.2020)

Görsel 7. https://www.artsy.net/artwork/marc-chagall-sculpted-vase-vase-sculpte (erişim 09.02. 2020) 
Görsel8.https://www.masterworksfineart.com/artists/georges-braque/sculpture/profil-profile-1960 /id/ w -5229 (09.02.2020)

Görse19.https://www.printed-editions.com/artist/jean-cocteau/le-d\%c3\%a9sir-1958-william-westongallery-ifpda/ (09.02.2020)

Görsel 10. https://successiomiro.com/catalogue/object/1135 (09.02.2020)

Görsel 11. http://www.artmulti.se/ceramicspageappel.htm (09.02.2020)

Görsel 12. https://www.bonhams.com/auctions/24296/lot/80/?category=list (09.02.2020)

Görsel 13. http://lebriz.com/pages/artist.aspx?artistID=612\&section=130\&lang=TR\&periodID=$1 \&$ bhcp $=1(09.02 .2020)$

Görsel 14. https://www.brooklynmuseum.org/exhibitions/dinner_party (09.02.2020)

Görsel 15. https://pennybyrneartist.com/works/21 (09.02.2020)

Görsel 16. http://www.jessicaharrison.co.uk/page14.htm (09.02.2020)

Görsel 17. https://www.liviamarin.com/\#/weite/ (09.02.2020)

Görsel18.https://www.tate.org.uk/whats-on/tate-modern/exhibition/unilever-series/unilever-seriesai-weiwei-sunflower-seeds (09.02.2020) 